\title{
The Extent to which OTSSA Journal (OTE) Reflects the Indigenous African Culture and Tradition from 2001-2016 ${ }^{1}$
}

\author{
DAVId Tuesday Adamo (RESEARCH FELlOW, UNiSA)
}

\begin{abstract}
This article examines the Old Testament Society of South Africa (OTSSA) Journal (Old Testament Essays, OTE) from 2001 to 2016 in order to determine the extent to which the published articles in OTE reflect the indigenous African culture and tradition. I will examine each volume of OTE available to me from 2001 to 2016, to determine the percentage of articles that reflect indigenous African culture and tradition. Even though OTSSA is an African association and its journal belongs to Africa and published in Africa by Africans who live in Africa, can one truly say that it reflects African OT studies or Eurocentric OT Studies? At the time when scholars all over the world are taking seriously the indigenous approach to the study of the Bible (OT), can one truly say that OTE is taking African OT studies or African contextual approaches seriously? This article's objective is basically to challenge OT scholars who have the advantage of living, studying, and lecturing in Africa, irrespective of colour, to take African OT Studies seriously.
\end{abstract}

\section{A INTRODUCTION}

It is needless to say that OTE is published by the Old Testament Society of South Africa and a journal accredited by the Department of National Education. Although it is published in South Africa, I can proudly say that it is also an international journal. I was impressed when I went back to my alma mater, Perkins School of Theology, Southern Methodist University, Dallas, Texas, USA, and while examining available journals on the shelf, lo and behold, I found OTE.

My objective is not to say that an Africentric ${ }^{2}$ approach is better than Eurocentric one or that one is more superior. There is no perfect approach

* Submitted: 30/10/2017; peer-reviewed: 22/01/2018; accepted: 01/03/2018. David T. Adamo, "The Extent to which OTSSA Journal (OTE) Reflects the Indigenous African Culture and Tradition from 2001-2016," OTE 31 no. 1 (2018): 42-65. DOI: https://doi.org /10.17159/2312-3621/2018/v31n1a4

1 This article was originally presented at the SASNES/OTSSA/LXXSA Conference in Pretoria, Sept. 5-8, 2017.

2 I prefer using Africentric rather than Afrocentric because Africa is spelled Africa and not Afroca. 
because both need each other. After all, most African biblical scholars are trained in the Eurocentric approach and it became the foundation of Afrocentric approach. $^{3}$

My main objective in writing this article is to examine $O T E$ and its articles in order to find out to what extent those articles reflect the indigenous African culture, tradition, and religion. While culture generally can be defined as the social behaviour and norms of human societies, tradition is a belief or behaviour passed down from one generation to another generation. Sometimes it is difficult to separate tradition and culture from religion. They all are interwoven.

My definition of African culture, tradition, and religion is African social behaviour and norms, beliefs and religion passed down from one generation to another generation. They include African customs, African names, ancient and modern. Biblical names such as Cush/Cushi/Cushite/Ethiopia, Libya, Egypt/Egyptian/Pharaoh, ${ }^{4}$ and other indigenous African modern and ancient names are examples. ${ }^{5}$ My definition of African culture, tradition and religion will also cover African hermeneutics or anything that has to do with Afrocentricity or African contextuality in the interpretation of a text. Any article that concerns black person or persons whether inside or outside African continent will be considered as reflecting African culture, tradition, and religion. ${ }^{6}$

I will like to determine the percentage of articles that reflect indigenous African culture and tradition. Even though OTSSA is an African association and its journal belongs to Africa and published in Africa by Africans who live in Africa, can one truly say that it reflects African OT studies or Eurocentric OT Studies? Old Testament scholars all over the world are taking seriously the

3 Perhaps, I should say that all my education including in Nigeria and America was Eurocentric. What I believe is that I owe my Afrocentric approach to my Eurocentric training.

4 I have discussed ancient Egypt as part of African country and Pharaohs as African kings in several articles: David Adamo, "The Portrayer of Africa and Africans in the Book of Jeremiah," IDS 32/1 (2018): forthcoming; David Adamo, “The African Joseph: His Contributions to Ancient Israel and Africa," ThViat 40/2 (2016): 32-63; David Adamo, "Portrayal of Africa and Africans in the Pentateuch and the Major Prophets: Implication for Christianity in Modern Africa," ThViat 38/1 (2014): 25-35; David Adamo, "The African Wife of Joseph, Asenath," JSem 22/2 (2013): 409-25; David Adamo, "The Nameless African Wife of Potiphar and Her Contribution to Ancient Israel, OTE 23/2 (2013): 221-246.

5 For further detail of these names see David Tuesday Adamo, Africa and the Africans in the Old Testament (Benin City, Nigeria: Justice Jeco Press and Publishers Ltd., 2005), which is the publication of his thesis: David Tuesday Adamo, "Africa and Africans in the Old Testament and Its Environments" (PhD diss., Baylor University, Waco, Texas, 1986).

6 David Adamo, "The Task and Distinctiveness of African Biblical Hermeneutics." OTE 28/1 (2015): 31-52. 
indigenous approach to the study of the Bible (OT), can one truly say that OTE is taking African OT studies or African contextual approaches seriously? This article also aims to challenge OT scholars in Africa, irrespective of colour, to take African OT Studies more seriously.

It is important to define what I consider to be African OT studies because this will be the criteria by which each article will be judged whether it reflects African culture, religion, and tradition. It may then be useful to ask the question what is the indigenous African OT Scholarship? Or what is African OT Studies? African Old Studies is the study of the OT text from a contemporary African Perspective, religion, and culture. It uses African experiences to express African concerns in the $\mathrm{OT}^{7}$ It is the formulation of interpretatio Africana in OT research. ${ }^{8}$ Specifically, this can be "the re-reading of the Christian scripture from a premeditatedly Africentric perspective" when the "analysis of the OT text is done from the perspective of African world-view and culture." ${ }^{9}$ It is the bringing of African life interest which may be healing, protection, or success, into the interpretation of the OT. ${ }^{10}$ In this case, the African context becomes the explicit subject of the interpretation. African OT scholarship means using Africa to interpret the OT and using OT to interpret Africa. ${ }^{11}$ Any article in OTE that reflects the above definition is considered African OT Studies or Africanized OT Studies. As already said, I will only be able to examine the articles from 20012016 that is available to me and I think that they are fairly representative of OTE. To determine whether an article is truly Afrocentric I will provide a brief summary of it.

7 C. Kwensi Dickson, "The Old Testament and African Theology," GBT 4 (1973): 31-41; Knut Holter, Old Testament Research for Africa (New York: Peter Lang, 2002), 1.

8 Holter, Research for Africa, 1.

9 Adamo, "Task and Distinctiveness"; David Adamo, Explorations in African Biblical Studies (Eugene, OR: WIPF and Stock Publishers, 2001), 6.

10 David Adamo, "What is African Biblical Studies?" in Decolonization of Biblical Interpretation in Africa, ed. Samuel O. Abogunrin (Ibadan: Nigerian Association for Biblical Studies, 2005), 17-31.

11 Knut Holter, "The Current State of Old Testament Scholarship in Africa: Where Are We at the Turn of the Century?" in Interpreting the Old Testament in Africa, ed. Mary Getui, Knut Holter, and Victor Zinkeuratire (New York: Peter Lang, 2001), 27 40. 


\section{B THE NEED FOR AFRICANIZED OLD TESTAMENT STUDIES IN AFRICA}

Since the 1960 scholars of African OT studies have shown an interest in African concerns and experiences by doing comparative work between the OT and what we may call African parallels. ${ }^{12}$

Many scholars have expressed the need for Africanizing OT Studies since the 1970s. Kwensi Dickson is one of the early African scholars who expressed the need for Africanizing the OT Studies because African Christian Theology is characterized by a predilection for OT. ${ }^{13}$ That predilection for the OT makes the need for African biblical scholarship to be crucial. John Pobee believes that biblical scholars should consider African tradition, religion and culture as "hermeneutics" in themselves. ${ }^{14}$ If African tradition and religion are hermeneutic it means that the need for this hermeneutic in African OT scholarship should not be debated. Teresa Hinga also agrees with Pobee when she advised biblical scholars to shift from Eurocentric to Africentric hermeneutical approaches to biblical interpretation. ${ }^{15}$

In 1993, Le Roux noted the fact that South African OT scholarship has most of the time been focussed on the ancient text instead of contemporary issues. ${ }^{16}$ Ferdinand Deist called on his colleagues to seek to produce "an indigenous South African tradition of Old Testament Scholarship," since nothing had been produced at that point. ${ }^{17}$ Knut Holter also noted the gap between the Western OT scholarship and African OT scholarship. ${ }^{18}$

Other needs for Africanized OT Studies include the fact that African indigenous materials can be externalized. It is also a fact that there is no continent that has been misrepresented like that of African culture, and religion.

Unfortunately, the OT has been used to justify the enslavement of African people and the theory of inferiority complex has been perpetrated by some Western exegetes. Many OT exegetes have propounded that ancient Israel saw

12 Eric Anum, "Comparative Readings of the Bible in Africa: Some Concerns," in The Bible in Africa: Transactions, Trajectories and Trends, ed. Gerald O. West and Musa W. Dube (Leiden: Brill, 2000), 457-73.

13 Dickson, "Old Testament," 31-41. Holter, Research for Africa, 1.

14 Teresa Hinga, "Reading with: An Exploration of the Interface between Critical and Ordinary Readings of the Bible: A Response," Semeia 73 (1996): 277-84.

15 Hinga, "Reading with," 277-84.

16 Jurie H. le Roux, A Story of Two Ways: Thirty Years of Old Testament Scholarship in South Africa (Pretoria: Verba Vitae, 1993).

17 Ferdinand Deist, "South African Old Testament Studies and the Future," OTE 5/3 (1992): 314-15.

18 Knut Holter, "It's not Only a Question of Money! Between the Myths and Meanings of the South and Money and Methods of the North," OTE 11 (1998): 240-54. 
Africans/black people as slaves. McKane sees the Cushi of 1 Sam 18 as black African Negro slave. ${ }^{19}$ Hammershaimb, Harper, Ullendorf, and others also think that the Kushites in Amos 9:7 were compared with Israelites because Israelites knew the Kushites who were dark-skinned and uncivilized people coming from a despised nation called Africa. ${ }^{20}$ According to them the children of Israel knew Cushites as slaves.

The marginalization of Africanized OT scholarship is a reality as many journals will indicate. Most African biblical Scholars are trained in the Western interpretative methodology and are therefore ignorant of what we called Westernized OT. It is then crucial for self-training in the African contextual interpretation.

\section{$1 \quad$ OTE 14 (2001)}

Vol 14/1 has 8 articles with none reflecting African indigenous religion, culture, and tradition.

Volume 14/2, New Series, has nine articles with only one reflecting African religion, culture, and tradition. This article is "What Differences do African Contexts Make for English Translations?" by Prof Madipoane Masenya (281-96). The article examines the Northern Sotho translation of the NRSV and the HB. It mentions the biases notable in the Northern Sotho translation of the Bible. Prof Masenya emphasized the need for "Africa-conscious Bible translation." Her cry also is that African must revive their languages and proudly speak it fluently.

However, Vol. 14/3 has 11 articles without any one reflecting African indigenous culture and tradition.

\section{$2 \quad$ OTE 15 (2002)}

Volume 15/1 contains 18 articles with only two reflecting African indigenous culture and tradition. “... But You Shall Let Every Girl Live': Reading Exodus 1:1-2:10 the Bosadi (Womanhood) Way," was authored by Madipoane Masenya (99-112). The main argument is that Exod 1:8-2:10, if read in Bosadi South African context, may mean the building of respect for female bodies. It actually emphasizes the importance of women as mothers, as midwives, and as nurses. Their ability to thwart Pharaoh's powerful order shows the power in women

19 William McKane, A Critical and Exegetical Commentary on Jeremiah I-XXV, ICC (Edinburg: T \& T Clark, 1986), 1143.

20 Erling Hammershaimb, The Book of Amos: A Commentary, trans. John Sturdy (New York: Schocken Books, 1970), 134; William R. Harper, A Critical and Exegetical Commentary on the Books of Amos and Hosea, ICC (New York: Charles Scribner's Sons, 1915), 19; Edward Ullendorf, Ethiopia and the Bible (Oxford: Oxford University Press, 1968), 19. 
which is hardly recognizing in a patriarchal society. Since this article deals with the African people (Egyptians) I consider it as part of African culture and tradition.

The second article, "And She Became 'Snow White': Numbers 12:1-16," is written by Jacqueline Williams (259-58). The article discussed the identity of the Cushite (black) woman the reason for her marginalization by ancient Israelite community but God favoured her. Mirriam and Aaron were punished for that reason. This article is related to Africa as it deals with a black woman which I mentioned above is Afrocentrism to be used as part of my criteria.

\section{OTE 16 (2003)}

Volume 16/1 has 9 articles with only one article reflecting African indigenous culture and tradition. This article "The Historical Development of Old Testament Interpretation in Africa" was written by David Adamo (9-33). The author contended that dating back to the biblical period (Jer 36:1-23 and Acts 8), through the period of NT and African church fathers to the modern period (African Biblical Hermeneutics), Africans have been involved in biblical interpretation.

Volume 16/2 has 21 articles with two reflecting African culture and tradition. The first article " "A Small Herb Increases Itself (Makes Impact) by Strong Odour': Re-Imagining Vashti in an African South African Context," was written by Madipoane Masenya (332-42). This article tries to re-imagine the Vashti figure in Esth 1 from the perspective of modern South African women in their struggle for survival in South Africa.

The second article, "Facing the Challenges of Disrupted Societies: Interacting with Micah 7:1-7 from a Perceived South African Context" was written by Willie Wessels (489-501). According to him, both socio-historical context and the exegete interpreting the text from a particular context do it in order to apply it to a specific context. He tries to approach Mic 7:1-7 from a perceived South African understanding of society. Since this article relates to a South African understanding of society I consider it African culture.

\section{$4 \quad$ OTE 17 (2004)}

Volume 17/1 has seven articles and none that reflects African indigenous religion, tradition, and culture.

However, volume 17/2 has 11 articles with only one article reflecting African religion and culture. "Bible Translation as Ideological Text Production - with Special Reference to the Cultural Factor and Psalm 137 in Chichewa" was written by Ernst R. Wendland (315-43). It discusses how Bible translation in the Chichewa language proves how ideological text production is real. 
Volume 17/3 has nine articles with only two of them reflecting indigenous culture and tradition.

The first article, "The Abuse of the Administration of Justice in 1 Kings 21:1-29 and its Significance for our South African Context," (389-403) was written by Elewani Farisani and Dorothy Farisani. The article traces the administration of justice in the OT and the administration of justice in South Africa and then explains the significance of abuse of administration of justice for South African Context. South Africa can learn from the administration of justice during the period of the settlement when the administration of justice was fair and just both to the plaintiff and the defendant. Since this article is a comparison of both OT and South African administration of justice it reflects African culture and tradition. The second article, "Teaching Western-Oriented Old Testament Studies to African students: An Exercise in Wisdom or in Folly?" was written by Madipoane Masenya (455-69). According to her the education brought by the West makes Africans/South African to be alien to their culture and tradition. The time has come to review the educational system especially OT curriculum to reflect African tradition and culture in order to stop the alienation of African people from their culture and tradition.

\section{$5 \quad O T E 18(2005)$}

Volume 18/1 has nine articles with one article that reflects African culture and tradition. "The New Covenant and the Challenge of Building a New and Transformed Community in DR Congo: A Contextual Reading of Jeremiah 31:31-34" was written by Bungihabaku Katho (109-23). He used Jeremiah 31:31-34 to interpret Africa (Congo). According to him, as the exile of ancient Israel lived together and forgiven one another so the people of DR Congo should forgive one another despite the war ravaging situation and live a new life with a new covenant. According to my understanding when an article in which the Bible is used to interpret Africa (this case Dr Congo) the article reflects African culture and tradition.

Volume 18/2 has 18 articles with two in the African context. The first one is by Magdel le Roux, "African Light on the New Moon Ceremony" (281-95). After comparing the African customs (moon ceremony) le Roux demonstrates that African culture can shed light on the understanding of the OT culture. The second article is "Israel and South Africa in Unity: The Same Old Di(ve)r(si)ty Tricks, as Narrated by the Prophets" is written by Gerrie Strydom (356-70). A systematic account of the injustices that the eighth-century prophets protested against was given. Such studies resemble what is happening in South Africa and what to do about it. 
Volume 18/3 has 30 articles with three articles in the African context. The first Article is "The African Wife of Abraham (Gn 16:1-16; 21:8-21)" by David Adamo and Erivwerho Eghwubare (455-71). It sought to establish the Africanness of Hagar, the wife of Abraham and her place in the salvific plan of God and Urhobo contextual marriage. According to the article Hagar is a model for contemporary African women.

The second article is "Contextuality' in (South) African Exegesis: Reflections on the Communality of our Exegetical Methodologies," by Louis Jonker (637-50). According to Jonker African hermeneutic is not the same with historical critical methods. It is contextual and has to do with the attitude of the communality in exegetical methodology. The article is African methodology which is influence by African culture and tradition-communality. The third article is "An African Methodology for South African Biblical Sciences: Revisiting the Bosadi (Womanhood) Approach," by Madipoane Masenya (Ngwan'a Mphahlele) (741-51). She disagrees with the colonial mentality that South Africa is not part of Africa and calls for pure African methodology that will foreground Africa in the future of biblical studies (Bosadi approach).This article concerns an African hermeneutic which I consider part of African culture and tradition.

\section{$6 \quad$ OTE 19 (2006)}

Volume 19/1 has 18 articles with two in the African context. So far the 2006/19 has the greatest number of articles in the African context. The first one is "The Relevance of Old Testament Science in/for Africa: Two False Pieties and Focused Scholarship," by Christo Lombaard (144-55). He calls the call for the Africentric approach to the OT "a false piety" because our subject is OT and not Africa. It related to African culture and tradition because it is a critic Africentric approach. The second article is "The Vocation of an African Biblical Scholar on the Margins of Biblical Scholarship" by Gerald West (307-36). The author believes that African Biblical Scholarship has achieved substantial consciousness as a discipline. There are many challenges with special demands on African Biblical scholars including accountability, and responsibility, criticality, identification, and contextuality among others.

Volume 19/2 has 23 articles with 13 articles on the African cultural context. "Let My People Stay! A Research Project on Africanization of Old Testament Studies" is by Knut Holter (377-92) who presented the first article about the result of the 12 projects on Africanization of the OT. The second article is "Challenging Poverty through Proverbs: An African Transformational Hermeneutic," written by Madipoane Masenya (Ngwan'a Mphahlele) (393-404). African proverbs have similarity with OT and can be used to understand the OT as African feels at home with the OT using African proverbs. The third article is “"The Poor Are Not Us': An Exploration into Possibilities of Old Testament and African Proverbs on Poverty," is by Lechion Peter Kimilike (418-28). The 
African heritage can be used by readers of the Bible for meaningful interpretation in the struggle against poverty in Africa today.

The fourth article is "“It's on the Old Mat that One Weaves the New One': The Dialogue between African Proverbs and Biblical Texts" by Willie van Heerden (429-40). There is a possibility of meaningful dialogue between African and OT proverbs. The fifth article is "Using the Old Testament to Interpret Africa: The Malagasy Religious Context," is by Magdel Le Roux (441-54). The argument is that Christianization processes in general throughout history interact positively with pre-Christian religion. The sixth article is "The Old Testament and the Malagasy Famadihana Ritual" by George Razafindrakoto (455-72). It discusses the use of OT texts for the set of traditional death and burial rituals in Madagascar. The seventh article is "The Old Testament outside the Realm of the Church: A Case from Madagascar" also by George Razafindrakoto (473-85). It discusses some cases of the use of OT interpretation in the context of Malagasy traditional religion. It can be used to legitimize traditional religion vis-à-vis Christianity. The eighth article is "Killed by Aids and Buried by Religion: African Female Bodies in Crisis" by Madipoane Masenya (Ngwan'a Mphahlele) (486-99). The article considers the crisis of African female bodies trapped between HIV/AIDS and religious texts because it is killing most African female bodies because the interpretations of various religious text have not provided a solution. The ninth article is "Finding Africa in the Old Testament: Some Hermeneutical and Methodological Considerations" by Willie van Heerden (500-24), whose article is concerned with finding Africa in the OT and the cultural dimension of OT interpretation with emphasis on post-colonial criticism.

Other articles include "Previously Unstoried Lives: The Case of Old Testament Cush and Its Relevance to Africa" by Philip Lokel (525-37). It recounts what the OT people say about Cush which the traditional Western scholars have ignored. "Moses and His Cushite Wife: Reading Numbers 12:1 with Undergraduate Students of Makerere University" was penned by Philip Lokel (538-57). He tries to argue that the Cushite wife of Moses in Num 12 is certainly an African black woman. "The Lemba, the 'People of the Book' in Southern Africa" was written by Magdel le Roux (548-57). The Lemba people remember their culture through collective memory and texts which is closely related to the OT like some other African continents.

Volume 19/3 has 30 articles with three in an African context. The first article is "Interpreting Solomon in Colonial and Post-Colonial Africa" by Knut Holter (851-62), who has a concern about how the OT tradition about King Solomon has been interpreted in Africa and how contemporary historical-critical OT scholarship in Africa is still colonial. It has a post-colonial Africa as the context. The second article, "The Cushites in the Chronicler's Version of Asa's Reign: A Secondary Audience in Chronicles?" is by Louis Jonker (863-81). He is concerned with how the Chronicler reinterpreted Asa's reign and made the 
Chronicler longer than the Deuteronomist parallel. It deals with the story of Asa and the Cushites (Africans). The third article is "Reflections of a Feminist Scholar from the Threshold between Africa and European Biblical Exegesis" by Frances Klopper (882-91). She is concerned with her experience as an African feminist biblical scholar relates to Africa and Europe inform of an autobiography.

\section{OTE 20 (2007)}

Volume 20/1 has 13 articles with none in an African context. ${ }^{21}$ However, vol. 20/2 has 14 articles with two in an African context. Solomon Olusola Ademiluka wrote the first article, "A Study of the Patriarchal Narratives (Gen 12-50) in an African Setting" (273-82). The article concerned itself with the similarities between the patriarchal narratives in Gen 12-50 and African legends of ancestry. The closeness is valuable for doing theology in Africa. The second article, "Hearing Scripture in African Contexts: A Hermeneutic of Grafting" is by Dorothy Akoto (283-306). Since the old way of interpreting the OT is no longer adequate for contemporary African people the author offers what she calls a "hermeneutic of grafting" as a metaphor for biblical interpretation in African (Ghanaian) context.

Volume 20/3 has 21 articles with three in an African context. The first article, "Rereading the Naaman Story (2 Kings 5:1-7) in the Context of Stigmatization of People Living with HIV and Aids in Africa" was written by Adekunle Dada (586-600). He discusses how the "Bible can be creatively read in other to promote healing, growth, and change, increasing the coping skills and adaptive functions." The paper discusses how the story of Naaman can be appropriated by free people living with HIV and AIDS from stigmatization and discrimination and holistic empowerment. The second article, "Exile and Suffering: Reading Psalm 77 in an African Context," was written by Liswanisu Kamuwanga (720-35). The article is concerned with bridging the historical gap between the biblical and African context. A comparative reading of Ps 77 can be illuminated as far as the darkness of colonialism and post-colonialism failure and suffering is concerned. Yahweh's concern and faithfulness can bring hope to the contemporary suffering. The third article, "Invisible Exiles? An African-South African Woman's Reconfiguration of 'Exile' in Jeremiah 21:1-10" is written by Madipoane Masenya (756-71). Exile is not only the forced movement from one's country of birth. It can mean the invisible suffering of South African women as there were untold stories of Babylonian exile. In light of this, the author tries to discuss and provide ways in which Jer 21:1-10 can be configured using present-

${ }^{21}$ I examined Snyman's article "Collective Memory and Coloniality of Being as a Hermeneutical Framework: A Partialised Reading of Ezra-Nehemiah" but according to my judgment it does not seem to meet the criteria of Indigenous African culture and tradition. 
day South Africa as a frame of reference. The three articles have the African continent as their context.

\section{OTE $21(2008)$}

Volume 21/2 has 19 articles with two in an African context. ${ }^{22}$ The first article, “A Negro, Naturally a Slave': An Aspect of the Portrayal of Africans in Colonial Old Testament Interpretation" was written by Knut Holter (373-82). It is an examination of how Africans were portrayed in the OT during the 19th century biblical interpretation that any black man is "naturally" a slave according to the colonial understanding of Africans. The second article, "The Witch in Psalm 59: An Afro-Centric Interpretation" was authored by Zacharias Kotzé (383-90). The Euro-American interpretation of the witch in Ps 59 has been called a traitor and unbeliever, but Kotzé in his Afrocentric interpretation believes that it refers to the African witch since it has the characteristic of a witch in Africa.

Volume 21/3 has 9 articles with three in an African context. The first article is "Reading Psalm 109 in African Christianity" by David Adamo (575-92). Even though Ps 109 is considered one of the problematic psalms, when approached Afrocentrically, it is an appeal to Yahweh for justice to get up and fight for the poor. In an African context, this very Psalm is used for protection, healing, and success. The second article, "Prayer for Protection: A Comparative Perspective on the Psalms in Relation to Lozi Traditional Prayers" by Liswanso Kamuwanga (670-91). This is a comparative analysis of African Religion and the OT which shows that there are great similarities between them and such fruitful dialogue can be achieved as a result. The third article, "Did Someone Say 'History'? In Africa We Say 'His Story'! A Study in African Biblical Hermeneutics with Reference to the Book of Daniel" is by Hans van Deventer (713-28). It discusses what constitutes an African approach to the biblical texts. A literary approach is preferred and a fruitful point of departure than a historical approach.

\section{$9 \quad$ OTE 22 (2009)}

Volume 22/1 has 11 articles with three in an African context. The first article is "The Sociological Functions of Funeral Mourning: Illustrations from the Old Testament and Africa" by Solomon Olusola Ademiluka (9-20). This article examines the sociological functions that both African and OT funeral mourning serves and the implication for theology in Africa. The second article is "Ngoma Lungundu: An African Ark of Covenant" written by Magdel Le Roux (102-25). The Lemba has some valuable traditions that are similar to that of the OT. Their oral culture reflects their world view. Their orality has parallels with the ancient Israelite tradition. The third article, "'For Better or for Worse?' - The (Christian) Bible and African Women" was written by Madipoane Masenya (ngwan'a

\footnotetext{
${ }^{22}$ Volume $21 / 1$ is not available to me and that is why I said above that I will only discuss the available ones.
} 
Mphahlele) (126-50). The article deals with why African women continue to cling to the Bible that has been historically used to oppress them in their various interpretative contexts. A communal Africana women reading strategy was employed to read some biblical text from the Bible. However, volume 22/2 has 14 articles and has none in an African context.

\section{OTE 23 (2010)}

While volume 23/2 has 11 articles with none in an African Context, volume 23/3 has 23 articles with four in an African context. The first article is "Teaching the History of Ancient Israel from an African Perspective: The Invasion of Sennacherib of 701 BCE as an Example" was written by David Adamo (473501). There is a problem with teaching OT in Africa because it is taught like it is in Europe and America. Egypt and Ethiopia are not regarded as part of Africa. The way the OT is taught in Africa will determine the future of OT in an African continent. The second article, "Parental Instruction in Differing Contexts: Using Hermeneutical Phenomenology to Understand Selected Biblical and African Proverbs" by Madipoane Masenya (ngwan'a Mphahlele) (728-51). She chose selected texts of the Bible and that of African Northern Sotho proverbs and drew similarities between them. The third article, "How the Methodist Church of Southern Africa Read Leviticus 18:22 and 20:13 in View of Homosexuality" was written by Ndikho Mtshiselwa (769-87). In order to make a contribution to African biblical hermeneutics, the author examines how MCSA read and interpret the text of Leviticus on Homosexuality. It also examines the inability of MCSA to provide a sound rationale to reject and accept homosexuality. The fourth article is "Unstructural Analysis of the Bible Reinforcing Unstructural Analysis of African Contexts in (South) Africa?" was written by Gerald West (861-88). The article confirms that what Mosala said concerning the "unstructural understanding of the Bible" has come to pass. The author concludes that the "unstructural understanding of the Bible might contribute to a more structural understanding of current African contextual realities." As said above, any article that mentions Africa is considered as African culture and tradition in this article.

\section{OTE 24 (2011)}

Volume 24/1 has 15 articles with three in an African context. The first article is "Towards an Ethical Reading of the Hebrew Bible in the Fight against HIV and AIDS" by Madipoane Masenya (Ngwan'a Mphahlele) and Lehlohonolo Bookholane (384-400). In this article, the problem of HIV and AIDS is said to be serious in Africa, South Africa in particular. Scholars have employed various readings to find the relationship between the HB and HIV and AIDS. According to the authors, the link between the HB and HIV and AIDS can be better resolved by taking a closer look at the literary narrative constructions themselves and identifying various ideologies in the quest to find any moral ethical or more holistic ethical readings. The second article in this volume is "Jeremiah's Royal 
Oracle: A Contextual Reading of 23:1-8 and 33:14-26 in the African Leadership Situation" by Joseph Mavinga (118-41). The royal oracle in Judean context is a real challenge with regard to loyal leadership that is capable of restoring social justice. When this text is adequately appropriated it can provide African leadership with insight on how to be loyal in managing public affairs. The third article is "An African Bible for African Readers: J. G. Shembe's Use of the Bible in the Sermon" by Nkosinathi Sithole (208-20). The article examines Shembe's use of the Bible and advised more research on the Shembe use of the Bible being done. According to him, while he appropriated the Bible for Africa in his church, he was also forced to denounce it as a foreign book because it negates African traditional religion.

Volume 24/2 has 11 articles with two in an African context. The first article is "The Role of Historical-Critical Methodology in African Old Testament Studies" by Knut Holter (377-89). The article looks at the role of historical critical methodology since 1960 and concluded that it has assisted when used in its context concerning institutional and methodological perspective. The second article is "'Looking into Black Eyes and Feel the Embarrassment': A Selected and Selective Reading of the Africana Bible" by Gerrie Snyman (464-91). The article is a reading of the Africana Bible from the white perspective. It includes the argument on decoloniality and the examination of selected chapters of the Africana Bible.

However, vol. 24/3 has 12 articles with three in an African context. The first article, "Seeing Tamar through the Prism of an African Woman: A Contextual Reading of Genesis 38" is by Alexander Abasili (555-73). Childlessness in an African context is a grave problem. The author applies the Gen 38 theological implication in an African context and suggests that informed reactions and solutions to the so-called grave problem of childlessness in marriage should be proffered. The second article, "Toward an Indigenous (Xhosa) South African Biblical Scholarship" was written by Ndikho Mtshishelwa (668-89). According to the author, whiteness that continues to influence the biblical text is problematic. The purpose of the article is to further the debate on a whiteness that results in a paradigm shift from a whiteness interpretation to an indigenous (Xhosa) biblical interpretation in order to unlock the ancient biblical texts. The third article, "Patrimonialism in the Causes of the Division of the Kingdom in Israel: A Reading of the Division Narrative from the Perspective of the Rwandan Context of Social Conflict," was written by Eraste Nyirimana (708-30). Divine disobedience is not the only cause of the division in Israel, but also social-economic situation. A comparison of ancient Israel situation and Rwandan socio-economic situation is similar and leads to the conflicts in both contexts. The fourth article is " "Peace' (שָثָלום)-Its Prerequisite and Promise: A Poetic Analysis and an Application of Psalm 85 to Africa" was written by Ernst Wendland (767-82). The prerequisite for peace is living a life that Yahweh desires from his saints. The importance of this psalms is that it 
encourages us to communicate the message of peace through different means to all people.

\section{OTE 25 (2012)}

Volume 25/1 has 12 articles with one in an African context. The article "Decolonizing Psalm 91 in an African Perspective with Special Reference to the Culture of the Yoruba people of Nigeria," is written by David Adamo (9-26). It is an attempt to read Psalm 91 in Yoruba cultural perspective. Psalm 91 is interpreted in the light of providing protection, healing, and success which is the greatest concern of the African people.

While vol. 25/2 has 12 articles with none in an African context, 25/3 has 16 articles with three in an African context. The first article is "Teaching and Interpreting the Old Testament in Africa: Written Word, Archaeology and Oral World," by Magdel le Roux (559-82). This is a comparative study of the Lemba and proto-Israelite customs and beliefs which shows that there are many resemblances of the two customs and beliefs. The second article, "Anything New under the Sun of South African Old Testament Scholarship? African Qoheleths' Review of OTE 1994-2010" is written by Madipoane Masenya (Ngwan'a Mphahlele) and Hulisani Ramantwana (598-637). The authors say "In African Qoheleths' view life is characterized by a chasing after the wind." "Innovation and change seem to be resisted as...there is nothing new under the sun." 23 This phrase in Qoheleths is used as a hermeneutical lens at the history of OT research by South Africans for the past 18 years. This present article does not approach his article using Qoheleth but African culture, tradition and religion as defined by him. The article traces the history of South African OT scholars over the past 18 years. The article, "The African and Western Hermeneutics Debate: Mimesis, The Book of Esther, and Textuality" was written by Gerrie Snyman (657-84). The article is about African and Western Hermeneutical debate using the book Esther with its mimesis. He concluded that the African and Western Hermeneutics debate must continue. The article has both an African and a Western contextual framework.

\section{OTE $26(2013)$}

Volume 26/1 has 9 articles with two in an African Context. The first one is "The Prohibition of Cross-Dressing in Deuteronomy 22:5 as a Basis for the Controversy among Churches in Nigeria on Female Wearing of Trousers" by Solomon Olusola Ademiluka (9-19). This is a critical examination of Deut 22:5 concerning the wearing of a trouser by women. The second article is "The Dissolution of the Monarchy, the Collapse of the Temple and the Elevation of

\footnotetext{
${ }^{23}$ Madipoane Masenya (ngwan'a Mphahlele) and Hulisani Ramantwana “Anything New under the Sun of South African Old Testament Scholarship? African Qoheleths' Review of OTE 1994-2010," OTE, 25/3 (2012): 598-637.
} 
Women in the Post-Exilic Period: Any Relevance for African Women's Theology?" is by Madipoane Masenya (Ngwan'a Mphahlele) (137-53). According to the author, the collapse of the monarchy helped to elevate the status of women. Biblical women's lives have something positive to offer to contemporary African women.

Volume 26/2 has 15 articles with three in an African context. The first one is "The Nameless African Wife of Potiphar and Her Contribution to Ancient Israel" written by David Tuesday Adamo (221-46). Mrs Potiphar behaved like any other woman who is childless in Africa. She is neither better off nor worse than any normal human being whose husband is a eunuch. Her behaviour brought about the elevation of Joseph. The second article is "Reading the Virtuous Woman of Proverbs 31:10-31 as a Reflection of the Attributes of the Traditional Miship Woman of Nigeria" by Joel Kamsen Tihitshak Biwul (275-97). This article shows the similarities between the qualities of the woman of Prov 31:1031 and the Miship woman within the Nigerian context. The third article is "A Gender-sensitive Ethical Reading of Old Testament Texts: The Role of African Women as Characters in the Texts and Exponents of the Text" by Nambalirwa Helen Nkabala (384-400). This is the discussion of the contribution of African women toward a gender-sensitive ethical reading of the OT texts. The author concludes by arguing that the story of Talitha Cum can make African women in the position to reawaken their strength.

Volume 26/3 has 18 with one in an African context. The article "Women and the Cry for Justice in Old Testament Court Narratives: An African Reflection" by Funlola Olojede (761-72). The author of this article believes that both within and beyond this topos women are crying out for justice. The article believes that for justice to reign in the continent women will have to cry for it on behalf of their children.

\section{OTE 27 (2014)}

Volume 27/1 has 16 articles and two in an African context. The first article, "Forever Trapped? An African Voice on Insider/Outsider Dynamics within South African Old Testament Gender-Sensitive Frameworks," is by Madipoane Masenya (Ngwan'a Mphahlele) (189-204). The article attempts to elaborate on insider/outsider dynamics as they are played out within selected South African OT gender-sensitive biblical scholars' work. The second article, "Re-Reading of 1 Kings 21:1-29 and Jehu's Revolution in Dialogue with Farisani and Nzimande: Negotiating Socio-Economic Redress in South Africa" was written by Ndikho Mtshiselwa (205-30). This article discusses the socio-economic injustice in South Africa and advocates that Jehu's revolution could be used as a model for socio-economic redress in South Africa. This article has the South African context compared with ancient Israel's context. 
Volume 27/2 has 22 with one in an African context. The article "Pregnancy and Psalms: Aspects of the Healing Ministry of a Nigerian Prophet" was written by Knut Holter (428-43). The article deals with the analysis of a healing ministry of a Nigerian prophet using Psalms for healing the diseases related to barrenness and pregnancy.

Volume 27/3 has 18 articles with two in an African context. The first article, "The Poor in the Book of Psalms and in Yoruba Tradition" was written by David Tuesday Adamo (797-815). This is a comparative study of the concept of the poor in the OT and Yoruba tradition. Many similarities were found. The second article, "Towards the Quest for Transforming Old Testament Scholarship: The Impact of Political and Socio-Economic Crises on Scholarship in Zimbabwe," was written by Temba Rugwig (1009-34). It has such a negative effect on scholarship in Zimbabwe.

\section{OTE 28 (2015)}

Volume 28/1 has nine articles with two in an African context. The first article, "God's Wrath and Judgment on Ethnic Hatred and Hope for Victims of Ethnic Hatred in Obadiah: Implications for Africa" was written by Yaw Adu-Gyamfi (11-30). It is a discussion on judgment on ethnic hatred in Obadiah and how God will administer justice in the land and its implication to Africa. The second article, The Task, and Distinctiveness of African Biblical Hermeneutics is written by David Tuesday Adamo. The paper deals with the nature of African cultural hermeneutics and spells out what is distinctive such as the Bible as power, African presence, identity and others. African hermeneutics is part of African culture as mentioned above.

Volume 28/2 has 15 articles with three in an African context. The first article, "Is there Shalom or not? Jeremiah, a Prophet for South Africa," was written by Georg Fischer (351-70). According to the author the message of Jeremiah and his figure has a bearing on South Africa. The Second article, "In the Ant's School of Wisdom: A Holistic African-South African Reading of Proverbs 6:6-11" was written by Madipoane Masenya (ngwan'a Mphahlele) (421-32). Israelite and African world view are similar. A lot of insight can be gained from Prov 6:6-11 concerning the interconnectedness between a human being and the earth. The insight can be very useful for Africa-South/Africa. The third article, "The Justice of God in his Anger: A Narrative Analysis of Isaiah 5:1-7 and its Implication for Socio-Economic and Security Challenges in Nigeria," was written by Samson Olanisebe (481-96). This is a narrative analysis of Isa 5:1-7 and compare the situation with the people in Nigeria who suffer in the midst of plenty.

Volume 28/3 has 16 articles with four in an African context. The first article, "Hannah's Ordeal of Childlessness: Interpreting 1 Samuel 1 through the Prism of a Childless African Woman in a Polygamous Family," was written by 
Adamo, "The Extent to which OTSSA," OTE 31/1 (2018): 42-65

Alexander Abasili (581-605). The author uses the childless ordeal of Hannah to mirror the plight of childless women in polygamous African families and calls for a just response to such families. The second article, "Ants, Spiders or Bees ... and Ticks? A Typology of Old Testament Scholarship in South Africa since 1994 within its African Context" was written by Hendrik Bosman (636-54). The author discusses the past two decades of OT scholarship in South Africa and suggested a way forward. The third article, "Context and Context Meet: A Dialogue between the Sitz im Leben of Psalm 23 and the South African Setting" is written by Ndikho Mtshiselwa (704-23). According to the author the situation of the Psalmist mirror and draw parallels between the context from which Ps 23 emerged and the context of the readers in South Africa. Therefore the Sitz im Leben of Ps 23 could have positive implications for South Africa.

\section{OTE 29 (2016)}

Volume 29/1 has 11 articles with three in an African context. The first article, “"Thou Shalt not Suffer a Witch to Live' (Exod 22:18) and Contemporary Akan Christian Belief and Practice: A Translational and Hermeneutical Problem," is written by Yaw Adu-Gyamfi (11-32). The article demonstrates that "Thou shall not suffer a witch to live" is an error in translation by the KJV version of the Christian Bible because it is a translational and hermeneutical problem since the Hebrew word for witch is not correct. It is a representational term used in Exodus by the redactor to reflect the idolatrous practice prohibited by Yahweh. According to the author, the Hebrew word translated to mean kill is also not correct. The second article, "What is He Doing at the Gate? Understanding Proverbs 31:23 and its Implication for Responsible Manhood in the Context of African Societies," is written by Joel Kamsen Tihitshak Biwul (33-60). The article addresses the unbalanced portrayal of a couple by paying close attention to a male figure in Prov 31:23. It encourages African male to play his role as a responsible husband. The third article, "Mind the Working-Class People! An African Reading of Leviticus 25:8-55 with Latino/a Critical Tools," was written by Ndikho Mtshiselwa (133-50). The author argues that the above passage has great implication for both the Latino and African people for justice.

Volume 29/2 has six articles with two in an African Context. The first article, "The Chronicler as a Biblical Paradigm for a Theology of Reconstruction in Africa: An Exploration of 2 Chronicles 6:32," is by Ntozakhe Simon Cezula (277-96). The article is a response to Jesse Mugambi's theology of reconstruction in Africa by his examination of $2 \mathrm{Chr} 6: 32$. According to the author, 2 Chr 6:32 can be very resourceful for a biblical paradigm for South African reconstruction process. The second article, "BRIEF NOTES: Searching for Affirming Notions of (African) Manhood in the Paean in Praise of the 'Éšet Hayil? One African Woman's Response to Joel K. T. Biwul's Article, 'What is He doing at the Gate?"' was written by Madipoane Masenya (Ngwan'a Mphahlele) (360-69). The article is a response to Biwul article. This article made 
the point that "women facing androcentric text are in need of reading themselves into places where they are not perceived to be present."

\section{COMMENTS AND ANALYSIS}

While the total articles published from 2001 to 2016 according to the volume in my possession is 600 , that of the total Africentric articles is 86 . This is 11 percent of the publications. The majority of contributors are white South African scholars with only a few black African scholars. Although it is a fact that the number of black scholars contributing has increased since 2001 yet from the statistic above it is still relatively very low. Perhaps, the low number of black contributors is affected by the low membership of OTSSA OT black scholars. I strongly believe that the low contribution of Africanized articles could have been remedied if South African OT scholars had listened to Deist, and Masenya (Ngwan'a Mphahlele) and Ramantswana's call for South African OT scholars to overcome the non-African, non-contextual, irrelevant approaches to OT. ${ }^{24}$

Out of 86, the scholar who has contributed most is Prof Madipoane Masenya (Ngwan'a Mphahlele) with 15 articles (against all odds, not only as a black person but also as a woman). No wonder she is the first black woman to obtain a Ph.D in OT in South Africa. I may be accused of prejudice for commending her, I believe that in a world where there are strong prejudice and oppression against women and where women's achievements are hidden behind men, I do not apologize for her but also being courageous, and prolific. Moreover, where the world is so quick to condemn those who do wrong, we must also be quick to commend those who do well in the course of a race. The statistic above shows that South African OT scholarships are white dominated with mainly Western ideas. It is my opinion that OT scholarship should also be more relevant to the majority of people on the continent than only for a few white folks on the African continent. It means the social location of the OT scholars in South Africa should compel South African and other African OT scholars to take indigenous African context more seriously.

\section{THE WAY FORWARD TO IMPROVE THE SITUATION}

(i) Increase in membership of OTSSA. This can be done through regular advertisement of OTSSA in other journals. This will certainly make people aware of the importance of the journal.

(ii) Temporary waiver of membership fees for those who are poor and from certain poor countries in Africa. The Society of Biblical Literature (SBL)

24 Deist, "South African"; Madipoane Masenya (Ngwan'a Mphahlele) and Hulisani Ramantswana, "Anything New under the Sun of South African Old Testament Scholarship? African Qoheleths' Review of OTE 1994-2010," OTE 25/3 2012: 598637. 
has given example for people from the Third World with the reduction of membership fees (\$15) only.

(iii) Encouragement for people to write in the African context of the OT. This concerns both black and white but more attention should be given to black scholars because the majority of them may not have the culture of writing. They may have been trained mainly in Eurocentric scholarship. Many may also hold the theory that even if I write about Africa or my culture, it might never be published in white-dominated journals.

(iv) Sponsorship of selected poor scholars, especially the black scholars from South Africa and other African countries.

\section{E CONCLUSION}

I think that African people who are born and live on the African continent should not be teaching and researching the same way OT is done in Euro-American institutions. Our research, despite our skin colour, should reflect African culture and tradition for it to be more relevant to the continent. Regardless of whether one is black or white, we are privileged to have been born and live in Africa, because that gives us advantages of doing the best OT African scholarship more than anyone else outside Africa. It seems to me that what is mostly done in OTE is to mimic Euro-American scholarship instead of African OT scholarship where we have an advantage and have something distinctive to teach Euro-American scholars all over the world. I, therefore, encourage biblical scholars from South African biblical and other African countries to take advantage of their social location and do productive African OT scholarship. OTE will, therefore, be more relevant to their respective communities. I believe there will be a new day in OT African scholarship all over the world if the above is done.

\section{BIBLIOGRAPHY}

Abasili, Alexander, "Seeing Tamar through the Prism of an African Woman: A Contextual Reading of Genesis 38," OTE 24/3 (2011): 555-73. . "Hannah's Ordeal of Childlessness: Interpreting 1 Samuel 1 through the Prism of a Childless African Woman in a Polygamous Family," OTE 28/3 (2015): 581-605. https://doi.org/10.17159/2312-3621/2015/v28n3a3

Adamo, David. Explorations in African Biblical Studies. Eugene, OR: WIPF and Stock Publishers, 2001.

."The Historical Development of Old Testament Interpretation in Africa." OTE 16/1 (2003): 9-33. ."What is African Biblical Studies?" Pages 17-31 in Decolonization of Biblical Interpretation in Africa. Edited by Samuel O. Abogunrin. Ibadan: Nigerian Association for Biblical Studies, 2005. . Africa and the Africans in the Old Testament. Benin City, Nigeria: Justice Jeco Press and Publishers Ltd., 2005. 
. "Africa and Africans in the Old Testament and Its Environments." Ph.D

Thesis, Baylor University, Waco, Texas, 1986.

. "Reading Psalm 109 in African Christianity," OTE 21/3 (2008): 575-92.

. "Teaching the History of Ancient Israel from an African Perspective: The

Invasion of Sennacherib of 701 BCE as an Example," OTE 23/3 (2010): 473-

501.

. "Decolonizing Psalm 91 in an African Perspective with Special Reference

to the Culture of the Yoruba people of Nigeria." OTE 25/1 (2012): 9-26.

. "The Nameless African Wife of Potiphar and Her Contribution to Ancient

Israel," OTE 26/2 (2013): 221-46.

. "The African Wife of Joseph, Asenath," JSem 22/2 (2013): 409-25.

. "Portrayal of Africa and Africans in the Pentateuch and the Major Prophets:

Implication for Christianity in Modern Africa," ThViat 38/1 (2014): 25-35.

. "The Poor in the Book of Psalms and in Yoruba Tradition," OTE 27/3

(2014): 797-815.

. "The Task and Distinctiveness of African Biblical Hermeneutics", OTE

28/1 (2015): 31-52.

. "The African Joseph: His Contributions to Ancient Israel and Africa,"

ThViat 40/2 (2016): 32-63.

. "The Portrayer of Africa and Africans in the Book of Jeremiah," IDS 32/1

(2018): forthcoming.

Adamo, David and Erivwerho Eghwubare. "The African Wife of Abraham (Gn 16:116; 21:8-21)," OTE 18/3 (2005): 455-71.

Ademiluka, Solomon Olusola, "A Study of the Patriarchal Narratives (Gen 12-50) in an African Setting," OTE 20/2 (2007): 273-82.

. "The Sociological Functions of Funeral Mourning: Illustrations from the

Old Testament and Africa," OTE 22/1 (2009): 9-20.

. "The Prohibition of Cross-Dressing in Deuteronomy 22:5 as a Basis for the

Controversy among Churches in Nigeria on Female Wearing of Trousers," OTE

26/1 (2013): 9-19.

Adu-Gyamfi, Yaw. "God's Wrath and Judgment on Ethnic Hatred and Hope for

Victims of Ethnic Hatred in Obadiah: Implications for Africa," OTE 28/1

(2015): 11-30. https://doi.org/10.17159/2312-3621/2015/v28n1a3

. "'Thou Shalt not Suffer a Witch to Live' (Exod 22:18) and Contemporary

Akan Christian Belief and Practice: A Translational and Hermeneutical

Problem," OTE 29/1 (2016): 11-32. https://doi.org/10.17159/2312-3621/2016 /v29n1a3

Akoto, Dorothy, "Hearing Scripture in African Contexts: A Hermeneutic of Grafting", OTE 20/2 (2007): 283-306.

Anum, Eric, "Comparative Readings of the Bible in Africa: Some Concerns." Pages 457-73 in The Bible in Africa: Transactions, Trajectories and Trends. Edited by Gerald O. West and Musa W. Dube. Leiden: Brill, 2000.

Biwul, Joel K T. "Reading the Virtuous Woman of Proverbs 31:10-31 as a Reflection of the Attributes of the Traditional Miship Woman of Nigeria." OTE 26/2 (2013): 275-97. 
."What is He Doing at the Gate? Understanding Proverbs 31:23 and its

Implication for Responsible Manhood in the Context of African Societies," OTE 29/2 (2016): 33-60.

Bosman, Hendrik. "Ants, Spiders or Bees ... and Ticks? A Typology of Old Testament Scholarship in South Africa since 1994 within its African Context." OTE 28/3 (2015): 636-54. https://doi.org/10.17159/2312-3621/2015/v28n5a5

Cezula, Ntozakhe. "The Chronicler as a Biblical Paradigm for a Theology of Reconstruction in Africa: An Exploration of 2 Chronicles 6:32." OTE 29/2 (2016): 277-96. https://doi.org/10.17159/2312-3621/2016/v29n2a4

Dada, Adekunle. "Rereading the Naaman Story (2 Kings 5:1-7) in the Context of Stigmatization of People Living with HIV and Aids in Africa." OTE 20/3 (2007): 586-600.

Deist, Ferdinand. "South African Old Testament Studies and the Future." OTE 5/3 (1992): 314-15.

Dickson, C. Kwensi. "The Old Testament and African Theology.” GBT 4 (1973): 3141.

Farisani, Elewani and Dorothy Farisani. "The Abuse of the Administration of Justice in 1 Kings 21:1-29 and its Significance for our South African Context." OTE 17/3 (2004): 389-403.

Fischer, Georg. "Is there Shalom or not? Jeremiah, a Prophet for South Africa." OTE 28/2 (2015): 351-70.

Harper, William R. A Critical and Exegetical Commentary on the Books of Amos and Hosea. ICC. New York: Charles Scribner's Sons, 1915.

Hammershaimb, Erling. The Book of Amos: A Commentary. Translated by John Sturdy. New York: Schocken Books, 1970.

Hinga, Teresa. "Reading with: An Exploration of the Interface between Critical and Ordinary Readings of the Bible: A Response." Semeia 73 (1996): 277-84.

Holter, Knut. "It's not Only a Question of Money! Between the Myths and Meanings of the South and Money and Methods of the North." OTE 11 (1998): 240-54.

" The Current State of Old Testament Scholarship in Africa: Where Are We at the Turn of the Century?" Pages 27-40 in Interpreting the Old Testament in Africa. Edited by Mary Getui, Knut Holter, and Victor Zinkeuratire. New York: Peter Lang, 2001. https://doi.org/10.3726/978-1-4539-1010-8 . Old Testament Research for Africa. New York: Peter Lang, 2002. . "Let My People Stay! A Research Project on Africanization of Old Testament Studies." OTE 19/2 (2006): 377-92. . "Interpreting Solomon in Colonial and Post-Colonial Africa." OTE 19/3 (2006): 851-62. . "A Negro, Naturally a Slave': An Aspect of the Portrayal of Africans in Colonial Old Testament Interpretation.” OTE 21/2 (2008): 373-82. . "The Role of Historical-Critical Methodology in African Old Testament Studies." OTE 24/2 (2011): 377-89. "Pregnancy and Psalms: Aspects of the Healing Ministry of a Nigerian Prophet." OTE 27/2 (2014): 428-43.

Jonker, Louis. "“Contextuality' in (South) African Exegesis: Reflections on the Communality of our Exegetical Methodologies." OTE 18/3 (2005): 637-50. . "The Cushites in the Chronicler's Version of Asa's Reign: A Secondary Audience in Chronicles?" OTE 19/3 (2006): 863-81. 
Kamuwanga, Liswanisu. "Exile and Suffering: Reading Psalm 77 in an African Context." OTE 20/3 (2007): 720-35. "Prayer for Protection: A Comparative Perspective on the Psalms in Relation to Lozi Traditional Prayers." OTE 20/3 (2008): 670-91.

Katho, Bungihabaku. "The New Covenant and the Challenge of Building a New and Transformed Community in DR Congo: A Contextual Reading of Jeremiah 31:31-34." OTE 18/1 (2005): 109-123.

Kemilike, Lechion. “"The Poor Are Not Us': An Exploration into Possibilities of Old Testament and African Proverbs on Poverty." OTE 19/2 (2006): 418-28.

Klopper, Frances. "Reflections of a Feminist Scholar from the Threshold between Africa and European Biblical Exegesis." OTE 19/3 (2006): 882-91.

Kotzé, Zacharias. "The Witch in Psalm 59: An Afro-Centric Interpretation." OTE 21/2 (2008): 383-90.

Le Roux, Jurie H. A Story of Two Ways: Thirty Years of Old Testament Scholarship in South Africa. Pretoria: Verba Vitae, 1993.

Le Roux, Magdel. "African Light on the New Moon Ceremony." OTE 18/2 (2005): 281-95. . "Using the Old Testament to Interpret Africa: The Malagasy Religious Context." OTE 19/2 (2006): 441-54. . "The Lemba, the 'People of the Book' in Southern Africa." OTE 19/2 (2006): 548-557. 25. . "Ngoma Lungundu: An African Ark of Covenant." OTE 22/1 (2009): 102"Teaching and Interpreting the Old Testament in Africa: Written Word, Archaeology and Oral World." OTE 25/3 (2012): 559-82.

Lokel, Philip. "Previously Unstoried Lives: The Case of Old Testament Cush and Its Relevance to Africa." OTE 19/2 (2006): 525-37.

. "Moses and His Cushite Wife: Reading Numbers 12:1 with Undergraduate

Students of Makerere University." OTE 19/2 (2006): 538-47.

Lombaard, Christo. "The Relevance of Old Testament Science in/for Africa: Two

False Pieties and Focused Scholarship." OTE 19/1 (2006): 144-55.

Masenya, Madipoane (ngwan'a Mphahlele). "What Differences do African Contexts

Make for English Translations?” OTE 14/2 (2001): 281-96. . “... But You Shall Let Every Girl Live': Reading Exodus 1:1-2:10 the

Bosadi (Womanhood) Way.” OTE 15/1 (2002): 99-112. "“A Small Herb Increases Itself (Makes Impact) by Strong Odour': Re-

Imagining Vashti in an African South African Context." OTE 16/2 (2003): 33242.

. "Teaching Western-Oriented Old Testament Studies to African Students:

An Exercise in Wisdom or in Folly?" OTE 17/3 (2004): 455-69. . "An African Methodology for South African Biblical Sciences: Revisiting the Bosadi (Womanhood) Approach." OTE 18/3 (2005): 741-51. . "Challenging Poverty through Proverbs: An African Transformational Hermeneutic." OTE 19/2 (2006): 393-404. "Killed by Aids and Buried by Religion: African Female Bodies in Crisis."OTE 19/2 (2006): 486-489. "Invisible Exiles? An African-South African Woman's Reconfiguration of

'Exile' in Jeremiah 21:1-10." OTE 20/3 (2007): 756-71. 
64 Adamo, "The Extent to which OTSSA," OTE 31/1 (2018): 42-65

."'For Better or for Worse?' - The (Christian) Bible and Africana Women."

OTE 22/1 (2009): 126-50.

. "Parental Instruction in Differing Contexts: Using Hermeneutical

Phenomenology to Understand Selected Biblical and African Proverbs." OTE

23/3 (2010): 728-51.

. "The Dissolution of the Monarchy, the Collapse of the Temple and the

Elevation of Women in the Post-Exilic Period: Any Relevance for African

Women's Theology?" OTE 26/1 (2013): 137-53.

. "Forever Trapped? An African Voice on Insider/Outsider Dynamics within

South African Old Testament Gender-Sensitive Frameworks." OTE 27/1

(2014): 189-204.

. "In the Ant's School of Wisdom: A Holistic African-South African Reading of Proverbs 6:6-11." OTE 28/2 (2015): 421-32.

. "BRIEF NOTES: Searching for Affirming Notions of (African) Manhood in the Paean in Praise of the 'Éšet Hayil? One African Woman's Response to Joel K. T. Biwul's Article, 'What is He doing at the Gate?'” OTE 29/2 (2016): 36069.

Masenya, Madipoane (ngwan'a Mphahlele) and Hulisani Ramantwana. "Anything New under the Sun of South African Old Testament Scholarship? African Qoheleths' Review of OTE 1994-2010." OTE 25/3 (2012): 598-637.

Masenya, Madipoane (ngwan'a Mphahlele) and Lehlohonolo Bookholane. "Towards an Ethical Reading of the Hebrew Bible in the Fight against HIV and AIDS." OTE 24/1 (2011): 94-117.

Mavinga, Joseph. "Jeremiah's Royal Oracle: A Contextual Reading of 23:1-8 and 33:14-26 in the African Leadership Situation." OTE 24/1 (2011): 118-41.

McKane, William. A Critical and Exegetical Commentary on Jeremiah I-XXV. ICC. Edinburg: T \& T Clark, 1986.

Mtshiselwa, Ndikho. "How the Methodist Church of Southern Africa Read Leviticus 18:22 and 20:13 in View of Homosexuality." OTE 23/3 (2010): 769-87.

. "Toward an Indigenous (Xhosa) South African Biblical Scholarship." OTE 24/3 (2011): 668-89.

. "Re-Reading of 1 Kings 21:1-29 and Jehu's Revolution in Dialogue with Farisani and Nzimande: Negotiating Socio-Economic Redress in South Africa." OTE 27/1 (2014): 205-30.

. "Context and Context Meet: A Dialogue between the Sitz-im Leben of Psalm 23 and the South African Setting." OTE 28/3 (2015): 704-23. https://doi. org/10.17159/2312-3621/2015/v28n3a9

. "Mind the Working-Class People! An African Reading of Leviticus 25:8-55 with Latino/a Critical Tools." OTE 29/1 (2016): 133-50. https://doi.org/10. $\underline{17159 / 2312-3621 / 2016 / \mathrm{v} 29 \mathrm{n} 1 \mathrm{a} 9}$

Nkabala, Nambalirwa. "A Gender- Sensitive Ethical Reading of Old Testament Texts: The Role of African Women as Characters in the Texts and Exponents of the Text." OTE 26/2 (2013): 384-400.

Nyirimana, Eraste. "Patrimonialism in the Causes of the Division of the Kingdom in Israel: A Reading of the Division Narrative from the Perspective of the Rwandan Context of Social Conflict." OTE 24/3 (2011): 708-30.

Olanisebe, Samson. "The Justice of God in his Anger: A Narrative Analysis of Isaiah 5:1-7 and its Implication for Socio-Economic and Security Challenges in 
Nigeria." OTE 28/2 (2015): 481-96. https://doi.org/10.17159/2312-

$3621 / 2015 / \mathrm{V} 28 \mathrm{~N} 2 \mathrm{~A} 14$

Olojede, Funlola. "Women and the Cry for Justice in Old Testament Court Narratives: An African Reflection." OTE 26/3 (2013): 761-72.

Razafindrakoto, George. "The Old Testament and the Malagasy Famadihana Ritual." OTE 19/2 (2006): 455-72.

. "The Old Testament outside the Realm of the Church: A Case from

Madagascar." OTE 19/2 (2006): 473-85.

Rugwih, Temba. "Towards the Quest for Transforming Old Testament Scholarship:

The Impact of Political and Socio-Economic Crises on Scholarship in

Zimbabwe." OTE 27/3 (2014): 1009-34.

Sithole, Nkosinathi. "An African Bible for African Readers: J. G. Shembe's Use of the Bible in the Sermon." OTE 24/1 (2011): 208-20.

Snyman, Gerrie. "'Looking into Black Eyes and Feel the Embarrassment': A Selected and Selective Reading of the Africana Bible." OTE 24/2 (2011): 464-91.

. "The African and Western Hermeneutics Debate: Mimesis, The Book of Esther, and Textuality." OTE 25/3 (2012): 657-84.

Strydom, Gerrie. "Israel and South Africa in Unity: The Same Old Di(ve)r(si)ty Tricks, as Narrated by the Prophets." OTE 18/2 (2005): 356-70.

Van Deventer, Hans. "Did Someone Say 'History'? In Africa We Say 'His Story'! A Study in African Biblical Hermeneutics with Reference to the Book of Daniel." OTE 21/3 (2008): 713-28.

Van Heerden, Willie. "“It's on the Old Mat that One Weaves the New One': The Dialogue between African Proverbs and Biblical Texts." OTE 19/2 (2006): 42940.

. "Finding Africa in the Old Testament: Some Hermeneutical and Methodological Considerations." OTE 19/2 (2006): 500-24.

Wendland, Ernst R. "Bible Translation as Ideological Text Production - with Special Reference to the Cultural Factor and Psalm 137 in Chichewa." OTE 17/2 (2004): 315-43.

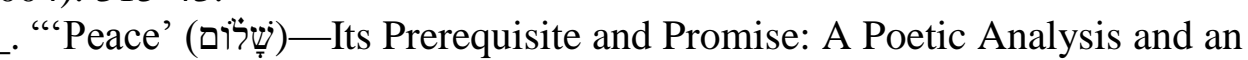
Application of Psalm 85 to Africa." OTE 24/3 (2011): 767-82.

Wessels, Willie. "Facing the Challenges of Disrupted Societies: Interacting with Micah 7:1-7 from a Perceived South African Context." OTE 16/2 (2003): 489501.

West, Gerald. "The Vocation of an African Biblical Scholar on the Margins of Biblical Scholarship." OTE 19/1 (2006): 307-36.

. "Unstructural Analysis of the Bible Reinforcing Unstructural Analysis of African Contexts in (South) Africa?" OTE 23/3 (2010): 861-88.

Williams, Jacqueline. “And She Became 'Snow White': Numbers 12:1-16.” OTE 15/2 (2002): 259-58.

Ullendorf, Edward. Ethiopia and the Bible. Oxford: Oxford University Press, 1968.

The Rev Prof David Tuesday Adamo, Department of Religious Studies, Kogi State University, Anyigba, Nigeria, Email- adamodt@ yahoo.com; ORCID ID: https://orcid.org/0000-0001-8610-4289 